\title{
ZBTB7A wt Allele
}

National Cancer Institute

\section{Source}

National Cancer Institute. ZBTB7A wt Allele. NCI Thesaurus. Code C52242.

Human ZBTB7A wild-type allele is located in the vicinity of 19q13.3 and is approximately $22 \mathrm{~kb}$ in length. This allele, which encodes zinc finger and BTB domain-containing protein $7 \mathrm{~A}$, is involved in cell cycle suppression. 